\title{
Parliament, Politics
}

\section{and Elections,}

\section{$1604-1648$}

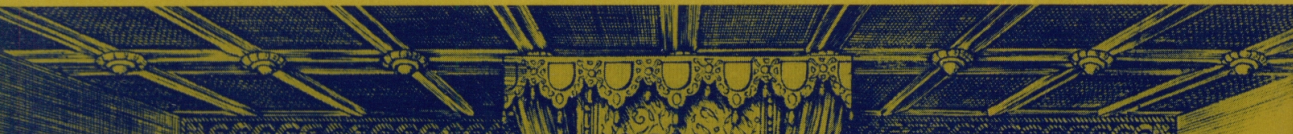

Edited by 1.

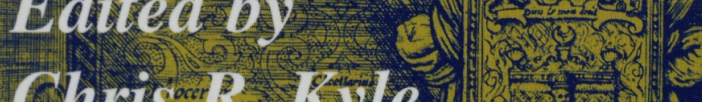

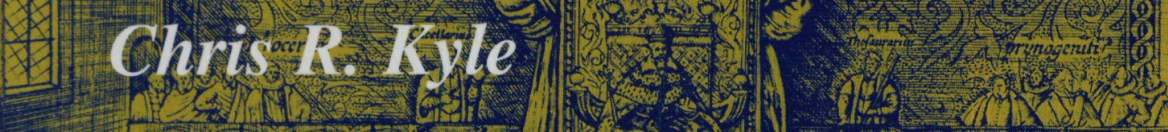
1.

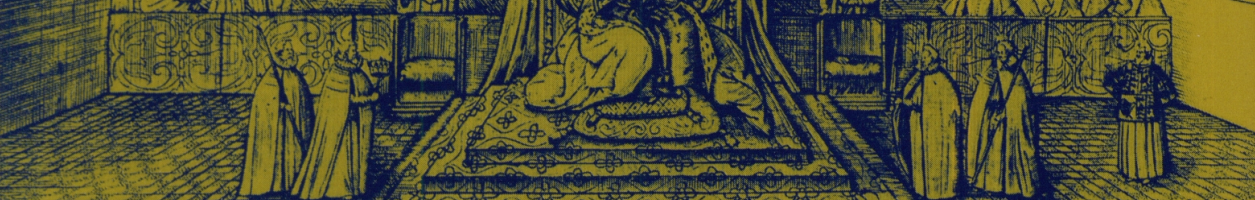

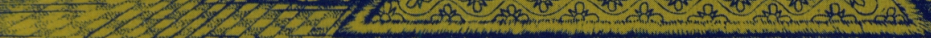




\section{PARLIAMENT, POLITICS \\ AND ELECTIONS \\ I604-1648}




\title{
PARLIAMENT, POLITIGS AND ELECTIONS 1604-1648
}

\author{
edited by \\ CHRIS R. KYLE
}

CAMDEN FIFTH SERIES

Volume 17

\section{WAMBRIDGE UNIVERSITY PRESS}

FOR THE ROYAL HISTORICAL SOCIETY

University College London, Queen Street, London wai 6вт 2001 
Published by the Press Syndicate of the University of Cambridge The Edinburgh Building, Cambridge CB2 2RU, United Kingdom 40 West 2oth Street, New York, NY iooli-421 I, USA 10 Stamford Road, Oakleigh, Melbourne 3166, Australia

(C) Royal Historical Society 2001

First published 200I

A catalogue record for this book is available from the British Libran

Library of Congress Cataloging-in-Publication Data

Parliament, politics and elections, $1604-1648$ / edited by Chris R. Kyle.

p. cm. - (Camden fifth series; v. 17)

Includes bibliographical references and index

ISBN 0-52I-80214-8

I. Great Britain. Parliament-History-17th century-Sources. 2. Great Britain-

Politics and government-1603-1649-Sources. I. Kyle, Chris R. II. Series.

DA20.C15 vol. 17

[J 534$]$

$94 \mathrm{I}$ s-dc2 I

[328.4I'og'o32]

$00-04555^{\circ}$

ISBN o $5^{21} 802148$ hardback

SUBSCRIPTIONS. The serial publications of the Royal Historical Society, Royal Historical Society Transactions (ISSN oo80-440I) and Camden Fifth Series (ISSN og60-1r63) volumes may be purchased together on annual subscription. The 2001 subscription price (which includes postage but not VAT) is $f_{60}$ (US\$99 in the USA, Canada and Mexico) and includes Camden Fifth Series, volumes 17 and 18 (published in July and December) and Transactions Sixth Series, volume II (published in December). Japanese prices are available from Kinokuniya Company Ltd, P.O. Box 55, Chitose, Tokyo 156, Japan. EU subscribers (outside the UK) who are not registered for VAT should add VAT at their country's rate. VAT registered subscribers should provide their VAT registration number. Prices include delivery by air.

Subscription orders, which must be accompanied by payment, may be sent to a bookseller, subscription agent or direct to the publisher: Cambridge University Press, The Edinburgh Building, Shaftesbury Road, Cambridge CB2 2RU, UK; or in the USA, Canada and Mexico: Cambridge University Press, Journals Fulfillment Department, I ro, Midland Avenue, Port Chester, NY 10573 4930, USA.

SINGLE VOLUMES AND BACK VOLUMES. A list of Royal Historical Society volumes available from Cambridge University Press may be obtained from the Humanities Marketing Department at the address above.

Printed and bound in the United Kingdom by Butler $\mathcal{F}^{\circ}$ Tanner Ltd, Frome and London 


\section{GONTENTS}

Acknowledgements

vii

Notes on Contributors $\quad$ ix

Abbreviations $\quad$ xi

Introduction I

Chris R. Kyle

I. Debates in the House of Commons, $1604^{-1607}$ I3 Simon Healy

2. War or Peace? Jacobean Politics and the Parliament of I62 I I49 Brennan Pursell

3. 'It will be a Scandal to show what we have done with such a number:' House of Commons Committee Attendance Lists, I606-I628

Chris R. Kyle

4. Tactical Organization in a Contested Election: Sir Edward Dering and the Spring Election at Kent, 1640 Jason Peacey

5. 'Particular Businesses' in the Long Parliament: The Hull Letters, I643- ${ }^{-1} 64^{8}$

David Scott

Index 